Article

\title{
Lipid A from Oligotropha carboxidovorans Lipopolysaccharide That Contains Two Galacturonic Acid Residues in the Backbone and Malic Acid A Tertiary Acyl Substituent
}

\author{
Adam Choma ${ }^{1}$, Katarzyna Zamłyńska ${ }^{1}$, Andrzej Mazur 1ㅁ, Anna Pastuszka ${ }^{1}$, \\ Zbigniew Kaczyński ${ }^{2}$ (D) and Iwona Komaniecka ${ }^{1, *(D)}$ \\ 1 Department of Genetics and Microbiology, Institute of Biological Sciences, Maria Curie-Sklodowska \\ University, Akademicka 19, 20-033 Lublin, Poland; adam.choma@poczta.umcs.lublin.pl (A.C.); \\ k.zamlynska@poczta.umcs.lublin.pl (K.Z.); mazur@hektor.umcs.lublin.pl (A.M.); \\ ak.pastuszka@poczta.umcs.lublin.pl (A.P.) \\ 2 Laboratory of Structural Biochemistry, Faculty of Chemistry, University of Gdansk, Wita Stwosza 63, \\ 80-308 Gdansk, Poland; zbigniew.kaczynski@ug.edu.pl \\ * Correspondence: ikoma@hektor.umcs.lublin.pl; Tel.: +48-81-537-5981
}

Received: 5 October 2020; Accepted: 24 October 2020; Published: 27 October 2020

\begin{abstract}
The free-living Gram-negative bacterium Oligotropha carboxidovorans (formerly: Pseudomonas carboxydovorans), isolated from wastewater, is able to live in aerobic and, facultatively, in autotrophic conditions, utilizing carbon monoxide or hydrogen as a source of energy. The structure of O. carboxidovorans lipid A, a hydrophobic part of lipopolysaccharide, was studied using NMR spectroscopy and high-resolution mass spectrometry (MALDI-ToF MS) techniques. It was demonstrated that the lipid A backbone is composed of two D-Glc $p$ N3N residues connected by a $\beta-(1 \rightarrow 6)$ glycosidic linkage, substituted by galacturonic acids (D-GalpA) at $\mathrm{C}-1$ and $\mathrm{C}-4^{\prime}$ positions. Both diaminosugars are symmetrically substituted by 3-hydroxy fatty acids (12:0(3-OH) and 18:0(3-OH)). Ester-linked secondary acyl residues (i.e., 18:0, and 26:0(25-OH) and a small amount of 28:0(27-OH)) are located in the distal part of lipid A. These very long-chain hydroxylated fatty acids (VLCFAs) were found to be almost totally esterified at the ( $\omega-1)-\mathrm{OH}$ position with malic acid. Similarities between the lipid A of O. carboxidovorans and Mesorhizobium loti, Rhizobium leguminosarum, Caulobacter crescentus as well as Aquifex pyrophylus were observed and discussed from the perspective of the genomic context of these bacteria.
\end{abstract}

Keywords: galacturonic acid; lipid A; lipopolysaccharide; malic acid; structure elucidation; VLCFA

\section{Introduction}

Oligotropha carboxidovorans strain OM5 is a Gram-negative slightly curved rod bacteria, possessing one lateral flagellum [1]. This bacterium was isolated from the soil of wastewater sewage treatment settling ponds near Götingen in Germany and was previously described as Pseudomonas carboxidovorans strain OM5 [2]. O. carboxidovorans can live in heterotrophic and chemolitho-autotrophic conditions. In the latter case, these bacteria can utilize carbon monoxide as a sole source of carbon and energy. Aerobically, they are able to oxidize approximately six molecules of $\mathrm{CO}$ to $\mathrm{CO}_{2}$ and simultaneously assimilate one of the produced $\mathrm{CO}_{2}$ molecules in the pentose phosphate pathway [3]. Oligotropha are economically important microorganisms, as they can oxidize syngas (i.e., a mixture of $\mathrm{CO}, \mathrm{CO}_{2}$, and $\mathrm{H}_{2}$ ) generated by biogasification of organic wastes [4]. Globally, such types of bacteria remediate more than 100 million tons of carbon monoxide from the atmosphere [5]. Heterotrophically, in aerobic conditions, 
these bacteria are able to use fixed carbon components (mainly organic acids) as a source of carbon and energy [6,7]. Oligotropha species interact with other bacteria forming co-aggregates. This phenomenon is important for proper settling of the sludge [8].

$16 \mathrm{~S}$ rDNA sequencing showed that $O$. carboxidovorans is phylogenetically related to the members of Bradyrhizobiaceae family, i.e., Bradyrhizobium sp. BTAi1, B. japonicum USDA110, and Nitrobacter hamburgiensis X14 [6]. Although the genomes of all these strains share some common genes and operons, these bacteria differ in their metabolism, which allowed them to adapt to very diverse environments. A huge diversity in the lipid A structure can be observed within the group of soil borne bacteria, called rhizobia, and the structure of several rhizobial lipids A has been described in details over the last twenty years [9]. Some of them, e.g., Sinorhizobium meliloti, produce a classical enterobacterial lipid A model, containing a biphosphorylated glucosamine-based lipid A backbone. Some species, e.g., Rhizobium leguminosarum, modify their lipid A via oxidation of proximal glucosamine (Glc $p \mathrm{~N})$ to 2-aminogluconate (GlcpAN). There is also a group, e.g., all members of the Mesorhizobium genus and the majority of species belonging to the Bradyrhizobium genus, which possess lipid A built of 2,3-diamino-2,3-dideoxy-D-glucose (Glc $p \mathrm{~N} 3 \mathrm{~N})$ instead of Glc $p \mathrm{~N}$, substituted at position C-1 with uronic acid. Lipid A of Mesorhizobium is in addition partly phosphorylated at position C-4' $[10,11]$. In turn, phosphate is absent in the lipid A of Bradyrhizobium, but position C-4' is occupied by two mannose residues forming a pentasaccharidic lipid A backbone [12-14]. The lipid A backbone in all Gram-negative bacteria is acylated by 3-hydroxy fatty acids, which are amide-linked at position C-2 and C-2' of Glc $p$ N and C-2, C-3, C-2', and C-3' of Glc $p$ N3N and ester-linked at position C-3 and C-3' of Glc $p$ N. Almost all members of rhizobia have very long-chain hydroxylated fatty acids (VLCFAs) linked as secondary substituents of 3-hydroxy fatty acids. VLCFAs contain 26 to 34 carbon atoms in the acyl chain, but rhizobia usually esterify their lipids A with 27-hydroxyoctacosanoic acid, which can be further acylated by 3-hydroxybutyrate as a tertiary residue. The presence of at least two or three very long-chain hydroxylated fatty acid (VLCFA) chains furnishing lipid A as secondary acyl residues has been confirmed in Bradyrhizobium [13,14].

Almost 30 years ago, it was shown that, similar to the bradyrhizobia, O. carboxidovorans (Pseudomonas carboxydovorans) contain 2,3-diamino-2,3-dideoxy-D-glucose in their lipid A [15]. The aim of presented study was to complete the structural analysis of lipid A isolated from the O. carboxidovorans OM5 lipopolysaccharide using modern analytical techniques, such as NMR spectroscopy and high-resolution mass spectrometry. Additionally, since the full genome sequence of $O$. carboxidovorans OM5 has been published [6,16], the comparative analysis of the region responsible for lipid A biosynthesis and its fatty acid substitution was performed. The corresponding gene sequences described for Mesorhizobium loti as well as Rhizobium leguminosarum and Sinorhizobium meliloti strains were used as the reference.

\section{Results}

\subsection{Isolation and Chemical Analysis of O. carboxidovorans Lipid A}

The LPS of O. carboxidovorans strain OM5 was extracted from delipidated and enzymatically digested cells with the hot $45 \%$ phenol/water method $[17,18]$. The LPS was found mainly in the water phase. Lipid A was obtained by mild acid (1\% acetic acid) hydrolysis of LPS and was subjected to fatty acid and sugar analyses. The sugar components of the O. carboxidovorans lipid A backbone were represented by 2,3-diamino-2,3-dideoxy-D-glucose (D-GlcN3N), and D-galacturonic acid (D-GalA). Among fatty acids, three amide-linked 3-hydroxy fatty acids (12:0(3-OH) and 14:0(3-OH) and 18:0(3-OH)) were identified, whereas ester-linked fatty acids were represented by a non-polar fatty acid (18:0) and two long $(\omega-1)$-hydroxylated fatty acids $(26: 0(25-\mathrm{OH})$ and 28:0(27-OH)) (Figure 1, Table 1$)$. All fatty acids were identified based on their chromatographic properties (retention times) and characteristic mass spectra. Additionally, a short-chain organic acid (malic acid) was found in the lipid A preparation. This component has been identified based on GC-MS analysis of TMSi-derivatives of butyl esters 
of volatile substances liberated from O. carboxidovorans lipid A. Authentic malic acid was used as a standard. Obtained derivatives of both substances co-eluted and gave the same mass spectra.

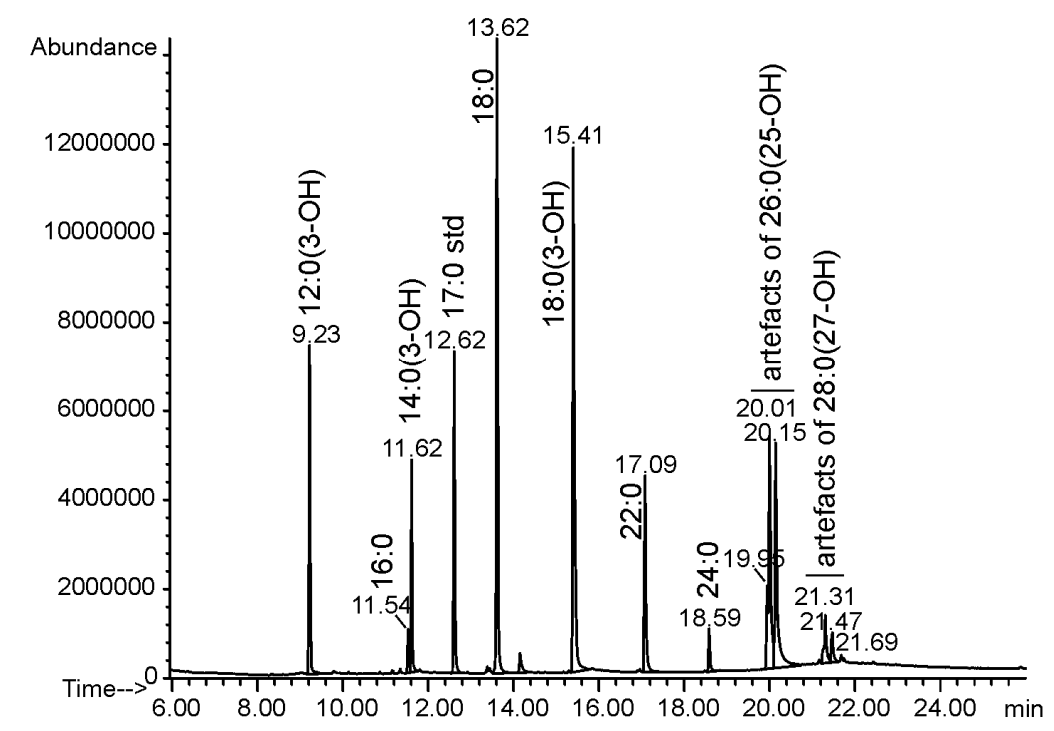

Figure 1. Fatty acid composition of O. carboxidovorans OM5 lipid A. Signals around $20 \mathrm{~min}$ and $21.30 \mathrm{~min}$ represent three isomers of the dehydrated form of 26:0(25-OH) and 28:0(27-OH), respectively, derived during strong acid hydrolysis ( $4 \mathrm{M} \mathrm{HCl}$ aq., $100{ }^{\circ} \mathrm{C}, 4 \mathrm{~h}$ ). For conditions of gas chromatography, see Materials and Methods section. Artefacts mean hydrolytically dehydrated hydroxy fatty acids. Std-internal standard.

Table 1. Fatty acid components of O. carboxidovorans OM5 lipid A.

\begin{tabular}{cc}
\hline Component & Amount $[\boldsymbol{\mu g} / \mathbf{m g}$ Lipid A] \\
\hline 12:0(3-OH $)$ & 39.7 \\
14:0(3-OH) & 24.5 \\
18:0(3-OH) & 95.7 \\
$16: 0$ & 5.7 \\
$18: 0$ & 93.7 \\
$18: 1$ & 4.6 \\
$22: 0$ & 33.2 \\
$24: 0$ & 6.5 \\
$26: 0(25-\mathrm{OH})$ & 112.5 \\
$28: 0(27-\mathrm{OH})$ & 18.2 \\
\hline
\end{tabular}

\subsection{NMR Spectroscopy of O. carboxidovorans Lipid A}

The native lipid A of O. carboxidovorans was dissolved in chloroform-d1/methanol-d4 (6:1, v/v) and structurally characterized by $1 \mathrm{D}$ and $2 \mathrm{D}$ NMR spectroscopy. As confirmed by ${ }^{31} \mathrm{P} \mathrm{NMR}$, the lipid A had no phosphate residues.

The HSQC-DEPT spectrum (Figure 2a) contained signals from four anomeric carbons $\left(\delta_{\mathrm{c}} 92.57-102.69\right)$, four signals of nitrogen-bearing carbons $\left(\delta_{\mathrm{c}} 51.65-54.12\right)$, signals of remaining sugar carbons $\left(\delta_{\mathrm{c}} 76.94-61.24\right)$, signals for $\mathrm{CH}-\mathrm{OH}$ and $\mathrm{CH}-\mathrm{OR}$ groups from hydroxylated fatty acids, and from the $\mathrm{CH}-\mathrm{OH}$ group of malic acid $\left(\delta_{\mathrm{c}} 67.16-73.39\right)$. Based on the ${ }^{1} \mathrm{H}-{ }^{1} \mathrm{H}$ COSY, TOCSY, and ${ }^{1} \mathrm{H}-{ }^{13} \mathrm{C}$ HMBC experiments four spin systems were identified, all deriving from hexopyranoses. Spin systems $\mathbf{A}$ and $\mathbf{D}$ derived from $\alpha$-D-Gal $p$ A residues, B represented $\alpha$-D-Glc $p$ N3N, and $C$ was assigned to $\beta$-D-Glc $p$ N3N. All ${ }^{1} \mathrm{H}$ and ${ }^{13} \mathrm{C}$ chemical shifts for the sugar backbone of $O$. carboxidovorans lipid A were assigned and listed in Table 2 . The anomeric configuration of all monosaccharides was confirmed by measuring the ${ }^{1} J_{(\mathrm{C} 1, \mathrm{H} 1)}$ coupling constants. Relatively large values of coupling constants (above $170 \mathrm{~Hz}$ ) for anomeric signals were 
found for residues $\mathbf{A}, \mathbf{B}$, and $\mathbf{D}$, thus identifying their $\alpha$-configuration. Residue $\mathbf{C}$ was characterized by a small $(161.1 \mathrm{~Hz})^{1} J_{(\mathrm{C} 1, \mathrm{H} 1)}$ coupling constant value, indicating its $\beta$-configuration.

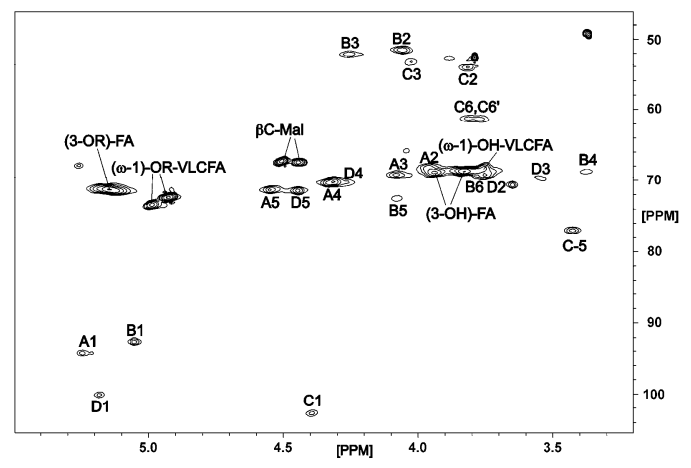

(a)

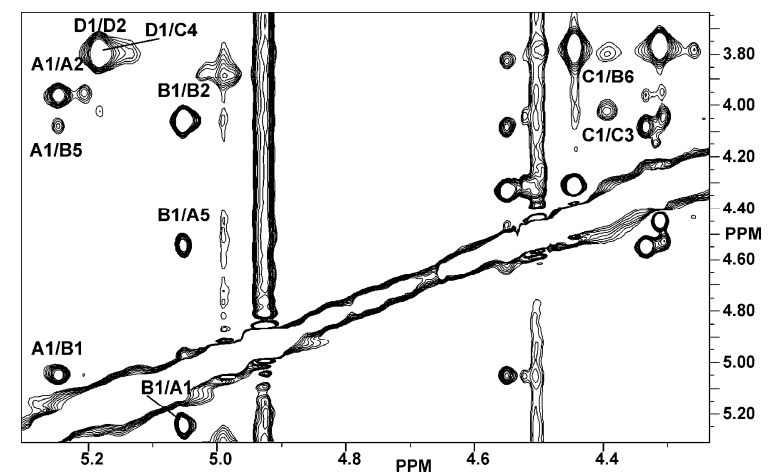

(b)

Figure 2. Part of the HSQC (a) and ${ }^{1} \mathrm{H}_{-}{ }^{1} \mathrm{H}$ ROESY (b) spectra of lipid A from O. carboxidovorans OM5. Only signals important for structural analysis are marked.

Table 2. ${ }^{1} \mathrm{H}$ and ${ }^{13} \mathrm{C}$ NMR chemical shifts [ $\delta$; ppm] of the O. carboxidovorans OM5 lipid A backbone.

\begin{tabular}{|c|c|c|c|c|c|c|c|}
\hline Spin System & $\begin{array}{c}{ }^{1} J_{(\mathrm{C}-1, \mathrm{H}-1)} \\
{[\mathrm{Hz}]}\end{array}$ & $\begin{array}{l}\text { H-1 } \\
\text { C-1 }\end{array}$ & $\begin{array}{l}\mathrm{H}-2 \\
\mathrm{C}-2\end{array}$ & $\begin{array}{l}\mathrm{H}-3 \\
\mathrm{C}-3\end{array}$ & $\begin{array}{l}\mathrm{H}-4 \\
\mathrm{C}-4\end{array}$ & $\begin{array}{l}\text { H-5 } \\
\text { C-5 }\end{array}$ & $\begin{array}{c}\text { H-6; H-6' } \\
\text { C-6 }\end{array}$ \\
\hline A, $\alpha-\mathrm{d}-\mathrm{Gal} p \mathrm{~A}-(1 \rightarrow$ & 173.8 & $\begin{array}{l}5.248 \\
94.24\end{array}$ & $\begin{array}{c}3.96 \\
68.62\end{array}$ & $\begin{array}{c}4.08 \\
69.13\end{array}$ & $\begin{array}{l}4.333 \\
70.34\end{array}$ & $\begin{array}{l}4.55 \\
71.3\end{array}$ & $\begin{array}{c}- \\
171.5\end{array}$ \\
\hline B,$\rightarrow 6)-\alpha-d-G l c p N 3 N-(1 \rightarrow$ & 171.8 & $\begin{array}{l}5.053 \\
92.57\end{array}$ & $\begin{array}{l}4.059 \\
51.65\end{array}$ & $\begin{array}{l}4.255 \\
52.23\end{array}$ & $\begin{array}{l}3.375 \\
68.73\end{array}$ & $\begin{array}{l}4.078 \\
72.48\end{array}$ & $\begin{array}{c}3.710 \\
3.710 \\
68.7\end{array}$ \\
\hline C, $\rightarrow 4)-\beta-d-G l c p N 3 N-(1 \rightarrow$ & 161.1 & $\begin{array}{c}4.395 \\
102.69\end{array}$ & $\begin{array}{c}3.816 \\
54.1\end{array}$ & $\begin{array}{l}4.027 \\
53.41\end{array}$ & $\begin{array}{l}3.825 \\
75.22\end{array}$ & $\begin{array}{l}3.427 \\
76.94\end{array}$ & $\begin{array}{l}3.773 ; \\
3.812 \\
61.24\end{array}$ \\
\hline D, $\alpha-\mathrm{d}-\mathrm{Gal} p \mathrm{~A}-(1 \rightarrow$ & 170.6 & $\begin{array}{c}5.189 \\
100.02\end{array}$ & $\begin{array}{l}3.796 \\
68.68\end{array}$ & $\begin{array}{l}3.773 \\
68.74\end{array}$ & $\begin{array}{l}4.316 \\
70.15\end{array}$ & $\begin{array}{l}4.446 \\
71.46\end{array}$ & $\begin{array}{c}- \\
170.5\end{array}$ \\
\hline
\end{tabular}

The ROESY spectrum (Figure 2b) showed the following connectivities between anomeric and linkage protons: A1/B1 ( $\delta 5.248 / 5.053), \mathbf{C 1} / \mathbf{B} 6$ ( $\delta$ 4.395/3.710), and D1/C4 ( $\delta 5.189 / 3.825)$. These data were confirmed by analysis of the HMBC spectrum, in which the following ${ }^{1} \mathrm{H}-{ }^{13} \mathrm{C}$ connectivities

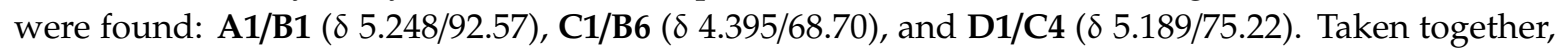
the sugar backbone of $O$. carboxidovorans lipid A has the following structure:

$$
\begin{array}{cccc}
\text { D } & \text { C } & \text { B } & \text { A } \\
\alpha-\mathrm{D}-G a l p A-(1 \rightarrow 4)-\beta-\mathrm{D}-\mathrm{Gl} p \mathrm{~N} 3 \mathrm{~N}-(1 \rightarrow 6)-\alpha-\mathrm{D}-\mathrm{Glc} p \mathrm{~N} 3 \mathrm{~N}-(1 \rightarrow 1)-\alpha-\mathrm{D}-\mathrm{Gal} p \mathrm{~A}
\end{array}
$$

The chemical shift values of the $\alpha, \beta$, and $\gamma$ carbons and protons of the 3-OH-fatty acids (both $3-\mathrm{O}-a c y l a t e d$ and those with a free $\mathrm{OH}$ group) and for signals derived from $\omega, \omega-1, \omega-2, \omega-3$, and $\omega-4$ protons and carbons of substituted as well as unsubstituted ( $\omega-1)$-hydroxylated long chain fatty acids were established and shown in Table 3. These data were similar to those reported for lipid A derived from B. elkanii or B. japonicum [12,13]. The NMR signals from $\alpha$ and $\beta$ carbons and protons as well as signals from carbons of carboxyl groups belonging to malic acid residues were identified as well. Two signals derived from $\beta-\mathrm{CH}$ proton and carbon at $\delta$ 4.505/67.16 and 4.446/67.41 were recognized. The signals derived from carbons of malic acid carboxyl groups ( $\delta 170.84$ and 173.30) showed an interresidue correlation with ( $\omega-1)$-hydrogens ( $\delta 4.929$ and 4.996 , respectively) from the long chain fatty acids in the HMBC spectrum. The signals of the $\beta-\mathrm{CH}$ group of unsubstituted 3-hydroxy fatty acids were identified at $\delta 3.833 / 68.80$ and 3.942/68.80. Two signals derived from the $\beta-\mathrm{CH}$ proton and 
carbon of 3-O-substituted fatty acids were found at $\delta 5.262 / 68.0$ and 5.145/71.29. The proton/carbon chemical shifts at $\delta 4.996 / 73.39$ and 4.929/72.36 were derived from the $(\omega-1)$ methine groups of the long chain fatty acids, which are connected to the $3-\mathrm{OH}$ group of the amide-linked fatty acids and bear malic acid as a tertiary residue.

Table 3. ${ }^{1} \mathrm{H}$ and ${ }^{13} \mathrm{C}$ NMR chemical shifts [ppm] of acyl substituents of O. carboxidoworans OM5 lipid A. Underling means assigning the signal to the specific group.

\begin{tabular}{|c|c|c|c|}
\hline Fatty Acid & Group & ${ }^{1} \mathbf{H}$ & ${ }^{13} \mathrm{C}$ \\
\hline \multirow{2}{*}{ Olefinic protons/carbons (double bond) } & $-\mathrm{CH}_{2}-\underline{\mathrm{HC}}=\mathrm{CH}-$ & 5.350 & 130.08 \\
\hline & $-\underline{\mathrm{CH}}_{2}-\overline{\mathrm{HC}}=\mathrm{CH}-$ & 2.016 & 27.49 \\
\hline \multirow{6}{*}{$\mathrm{I}^{\mathrm{st}}-\left(3-\mathrm{OR}^{\prime}\right)-\mathrm{FA}$} & $\alpha_{1} / \alpha_{2}$ & $2.620 / 2.504$ & 41 \\
\hline & $\beta$ & 5.145 & 71.29 \\
\hline & $\gamma$ & 1.588 & 34.4 \\
\hline & R-CONH-Sug & & 171.51 \\
\hline & R-COO- & & 174.53 \\
\hline & $\omega$ & 1.59 & 19.8 \\
\hline \multirow{5}{*}{$\mathrm{II}^{\mathrm{nd}}-\left(3-\mathrm{OR}^{\prime \prime}\right)-\mathrm{FA}$} & $\alpha_{1} / \alpha_{2}$ & $2.614 / 2.401$ & 40.9 \\
\hline & $\beta$ & 5.262 & 68 \\
\hline & $\gamma$ & ND & ND \\
\hline & R-CONH-Sug & & 169.72 \\
\hline & R-COO- & & ND \\
\hline \multirow{6}{*}{$\mathrm{I}^{\mathrm{st}}-[(\omega-1)-\mathrm{OR}]-\mathrm{VLCFA}$} & $\omega$ & 1.222 & 19.8 \\
\hline & $\omega-1$ & 4.996 & 73.39 \\
\hline & $\omega-2$ & $1.600 / 1.486$ & 36 \\
\hline & $\omega-3$ & 1.41 & 25.5 \\
\hline & $\omega-4$ and next $\mathrm{CH}_{2}$ groups & 1.59 & 29.8 \\
\hline & $\mathrm{R}-(\mathrm{COO}-)$ from malic acid & & 173.3 \\
\hline \multirow{6}{*}{$\mathrm{II}^{\mathrm{nd}}-[(\omega-1)-\mathrm{OR}]-\mathrm{VLCFA}$} & $\omega$ & 1.222 & 19.8 \\
\hline & $\omega-1$ & 4.929 & 73.36 \\
\hline & $\omega-2$ & $1.600 / 1.488$ & 36 \\
\hline & $\omega-3$ & 1.474 & 25.5 \\
\hline & $\omega-4$ and next $\mathrm{CH}_{2}$ groups & 1.59 & 29.8 \\
\hline & $\mathrm{R}-(\mathrm{COO}-)$ from malic acid & & 170.84 \\
\hline \multirow{5}{*}{$\mathrm{I}^{\text {st }}-(3-\mathrm{OH})-\mathrm{FA}$ with unsubstituted $\mathrm{OH}$ group } & $\alpha_{1} / \alpha_{2}$ & $2.339 / 2.252$ & 43.9 \\
\hline & $\beta$ & 3.942 & 68.8 \\
\hline & $\gamma$ & 1.435 & 37.5 \\
\hline & $\delta$ & 1.399 & 25.8 \\
\hline & $\mathrm{CH}_{2}$ groups from acyl chain & 1.266 & 29.9 \\
\hline \multirow{5}{*}{$\mathrm{II}^{\text {nd }}-(3-\mathrm{OH})-\mathrm{FA}$ with unsubstituted $\mathrm{OH}$ group } & $\alpha_{1} / \alpha_{2}$ & $2.307 / 2.201$ & 43.05 \\
\hline & $\beta$ & 3.833 & 68.8 \\
\hline & $\gamma$ & 1.435 & 37.6 \\
\hline & $\delta$ & 1.399 & 25.7 \\
\hline & $\mathrm{CH}_{2}$ groups from acyl chain & 1.266 & 29.9 \\
\hline \multirow{4}{*}[(\omega-1)-\mathrm{OH}]{ VLCFA with unsubstituted $\mathrm{OH}$ group } & $\omega-1$ & 3.756 & 68.4 \\
\hline & $\omega-2$ & $1.387 / 1.478$ & 39.34 \\
\hline & $\omega-3$ & 1.28 & 26.05 \\
\hline & $\omega-4$ and next $\mathrm{CH}_{2}$ groups & 1.59 & 29.94 \\
\hline \multirow{4}{*}{$\mathrm{I}^{\text {st }}$ Malic acid } & $\alpha_{1} / \alpha_{2}$ & $2.860 / 2.717$ & 39.41 \\
\hline & $\beta$ & 4.505 & 67.16 \\
\hline & $\mathrm{COO}-$ & & 170.84 \\
\hline & R-COO- & & 175.36 \\
\hline \multirow{4}{*}{ II $^{\text {nd }}$ Malic acid } & $\alpha_{1} / \alpha_{2}$ & $2.860 / 2.717$ & 39.24 \\
\hline & $\beta$ & 4.446 & 67.41 \\
\hline & $\mathrm{COO}-$ & & 170.58 \\
\hline & $\mathrm{R}-\mathrm{COO}-$ & & 173.3 \\
\hline
\end{tabular}




\subsection{Mass Spectrometry of O. carboxidovorans Lipid A}

Mass spectrometry experiments were performed in the positive and negative ion modes of native lipid A preparations. Figure 3 shows the negative-ion MALDI-TOF mass spectrum of the native lipid A sample.

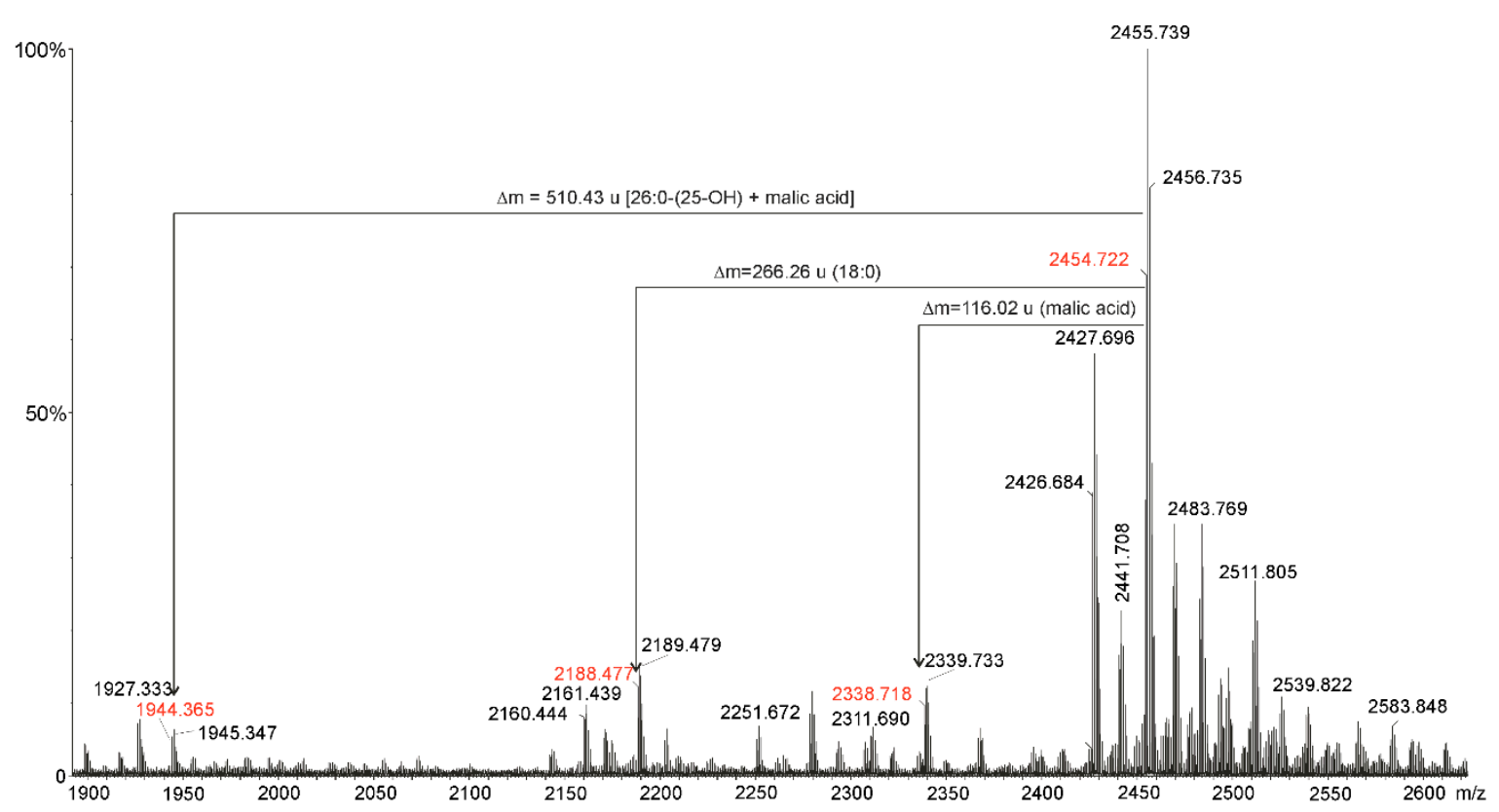

(a)

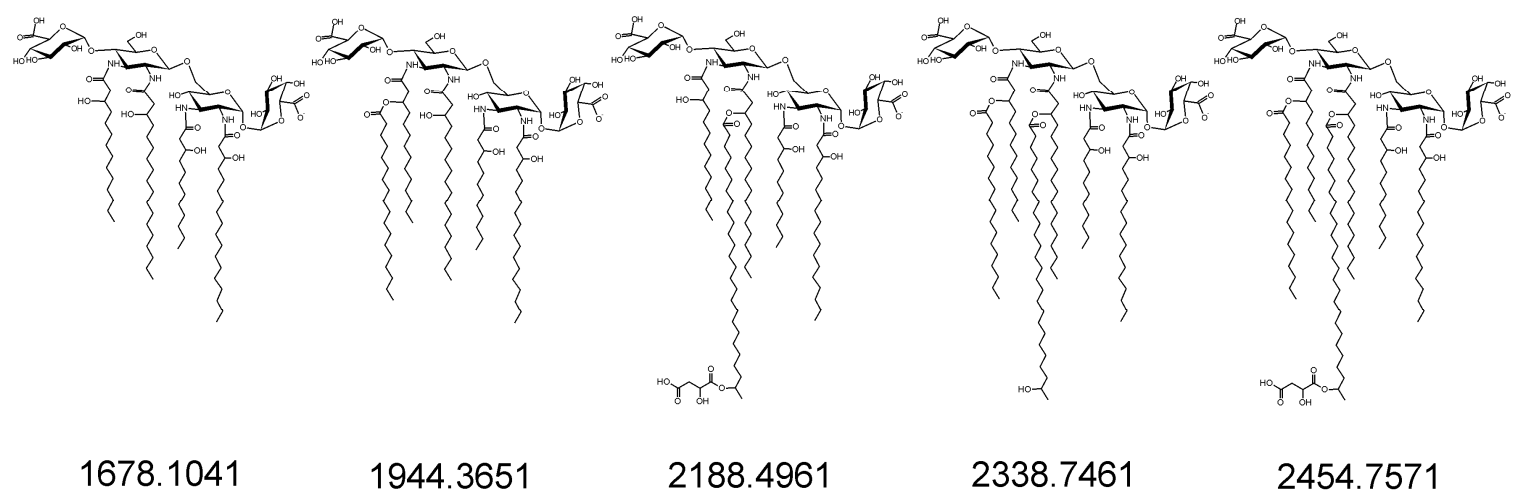

(b)

Figure 3. Negative mode MALDI-TOF mass spectrum of native lipid A from O. carboxidovorans OM5 (a); proposed formulas of lipid A ions presented in the lipid A mass spectrum (with calculated $\mathrm{m} / \mathrm{z}$ values) (b). The $m / z$ values marked in red at part (a) refer to the relevant chemical formulas given in part (b) of the figure.

Based on the chemical analyses of the sugar components and fatty acid residues, the most abundant signal at $m / z 2454.722$ could be assigned to lipid A molecules containing two Glc $p$ N3N residues, two GalpA units, 12:0(3-OH), 14:0(3-OH), two 18:0(3-OH) fatty acid residues, and two ester-linked fatty acids: 18:0 and 26:0(25-OH) acids. The last one was additionally esterified by malic acid. Around this signal, one can distinguish a number of others with a lower intensity. The mass differences between the next two (e.g., $\mathrm{m} / \mathrm{z} 2441.708$ and 2455.739 or 2427.696 and 2455.739) correspond to the mass of a single or double methylene groups (14 or $28 \mathrm{u}$ ), as a result of a different acylation 
pattern. Moreover, this spectrum (Figure 3) contains signals corresponding to lipid A molecules lacking an octadecanoate $(\mathrm{m} / \mathrm{z}$ at 2188.477$)$ or acyloxyacyl $(26: 0(25-\mathrm{OH})+$ malate, $\mathrm{m} / \mathrm{z}$ at 1944.382$)$ residue or both substituents simultaneously $(\mathrm{m} / \mathrm{z}$ at 1678.123 , traces). As a result, all of these signals should be thought to prove the existence of the whole set of particles being variants of lipid A differing in acyl substitution and acyl substituents. It should be noted, however, that most of the molecules in the preparation are lipid A molecules substituted with seven acyl residues (four 3-OH-fatty acids, one VLCFA, one non-polar acid, and malic acid). Based on the analysis of the intensity of the respective ions in the mass spectrum of native lipid A, it was estimated that ca. $85 \%$ of the molecules in the preparation were heptaacylated lipid A. Each of the negative ions described above corresponds to two ions $\left([\mathrm{M}+\mathrm{H}]^{+}\right.$and $\left.[\mathrm{M}+\mathrm{Na}]^{+}\right)$, which could be observed in the MALDI-TOF spectrum in the positive-ion mode. Fragmentary positively charged ions were observed in this spectrum as well. The most informative of these are $\mathrm{B}^{+}$type ions. An ion at $m / z 2262.726$ was identified. It can be treated as a $\mathrm{B}_{3}{ }^{+}$ion. Its presence indicates substitution of the lipid A sugar backbone at the $\mathrm{C}-1$ position by a galacturonic acid residue. The ion at $m / z 1622.242$ represents a $\mathrm{B}_{2}{ }^{+}$charged molecule and indicates asymmetrical distribution of secondary and tertiary fatty acids in lipid A molecules. These (VLCFA, 18:0 and malic acid) decorate the distal Glc $p$ N3N in lipid A molecules. Moreover, the presence of ions in the spectra (both positive and negative-ion modes) representing lipid A molecules lacking malate $(\mathrm{m} / \mathrm{z} 2338.752$ in negatiove-ion mode) and lacking both the VLCFA residue and the malic acid residue $(\mathrm{m} / \mathrm{z} 1944.382$ in negatiove-ion mode), as well as the simultaneous absence of ions corresponding to lipid A molecules lacking VLCFA but not malate clearly demonstrate that VLCFA and malic acid form an acyloxyacyl residue having the following structure 26:0[25-O- $(\mathrm{C}=\mathrm{O}) \mathrm{CH}_{2} \mathrm{CH}(\mathrm{OH}) \mathrm{COOH}$.

Positive-ion mode MS/MS analysis was performed to reveal the exact positions of the lipid A acyl moieties (and in this way to prove the conclusions formulated above). The MALDI TOF MS/MS spectrum of the ion at $m / z 2478.775\left[\mathrm{M}_{\text {heptaacyl }}+\mathrm{Na}\right]^{+}$is shown in Figure 4. Ion peaks originating from cleavage of the glycosidic linkage, marked as B, C, and Y (according to Domon and Costello nomenclature [19]) are not prominent and not very intense in this spectrum. Two of them exhibit slightly higher intensity and can undoubtedly be attributed to specific chemical structures; moreover, monoisotope masses calculated on the basis of the proposed formulas fits the experimental data very well. The first ion is at $m / z 2303.736$. It can be interpreted as the sodiated ion of the $C_{3}$ type or as the sodiated ion of the $Y_{3}$ type. Both have identical molecular masses and both arise through the elimination of GalpA from lipid A (parent ion). The second ion observed at $\mathrm{m} / z$ 1644.204 is marked as $\mathrm{B}_{2}{ }^{+}$. This fragment ion is made up of one GalpA, one GlcpN3N, two 3-hydroxylated fatty acids $\left(14: 0(3-\mathrm{OH})\right.$, and 18:0(3-OH) ) and 18:0 as well as $26: 0\left(25-\mathrm{O}-(\mathrm{C}=\mathrm{O}) \mathrm{CH}_{2} \mathrm{CH}(\mathrm{OH}) \mathrm{COOH}\right)$ moieties. The composition of this ion complements the sodium atom. Further fragmentation of $\mathrm{B}_{2}{ }^{+}$yields two predominant ions in the spectrum. Elimination of VLCFA (with its $O$-acyl substituent) leads to an ion at $m / z 1115.816$ and subsequent elimination of Gal $p$ A gives an ion at $m / z$ 939.785. The loss of octadecanoic acid $(\Delta=284.26 \mathrm{u})$ from both ions described above gives rise to ions at $\mathrm{m} / \mathrm{z} 831.543$ and 655.506, respectively. The last prominent signal in the spectrum at $\mathrm{m} / \mathrm{z} 360.291$ corresponds to the $\mathrm{C}_{21} \mathrm{H}_{39} \mathrm{~N}_{1} \mathrm{O}_{2} \mathrm{Na}$ formula (theoretically calculated monoisotopic mass $360.2873 \mathrm{u}$ ) and is presumably made up of dehydrated 18:0(3-OH) connected via an amide bond to a fragment of the distal GlcN3N including only the $\mathrm{C} 1, \mathrm{C} 2$, and $\mathrm{C} 3$ carbons and one oxygen.

The fragmentations described above clearly indicate that two acyls (18:0 and 26:0(25-O-(malic acid)) are ester-linked, thus demonstrating that they occur as secondary fatty acids. Moreover, this observation unambiguously proved again that both secondary O-substitutions occurred on the non-reducing Glc $p$ N3N unit. Therefore, O. carboxidovorans OM5 displayed a lipid A structure with an asymmetric distribution of the acyl moieties with respect to the di-Glc $p$ N3N backbone (symmetry $4+2$ or, more precisely, taking into account malic acid as a separate residue, the symmetry should be written as follows: $5+2$ ).

Summing up all the experimental data, a probable structural formula of lipid A from O. carboxidovorans OM5 can be proposed (Figure 5). 


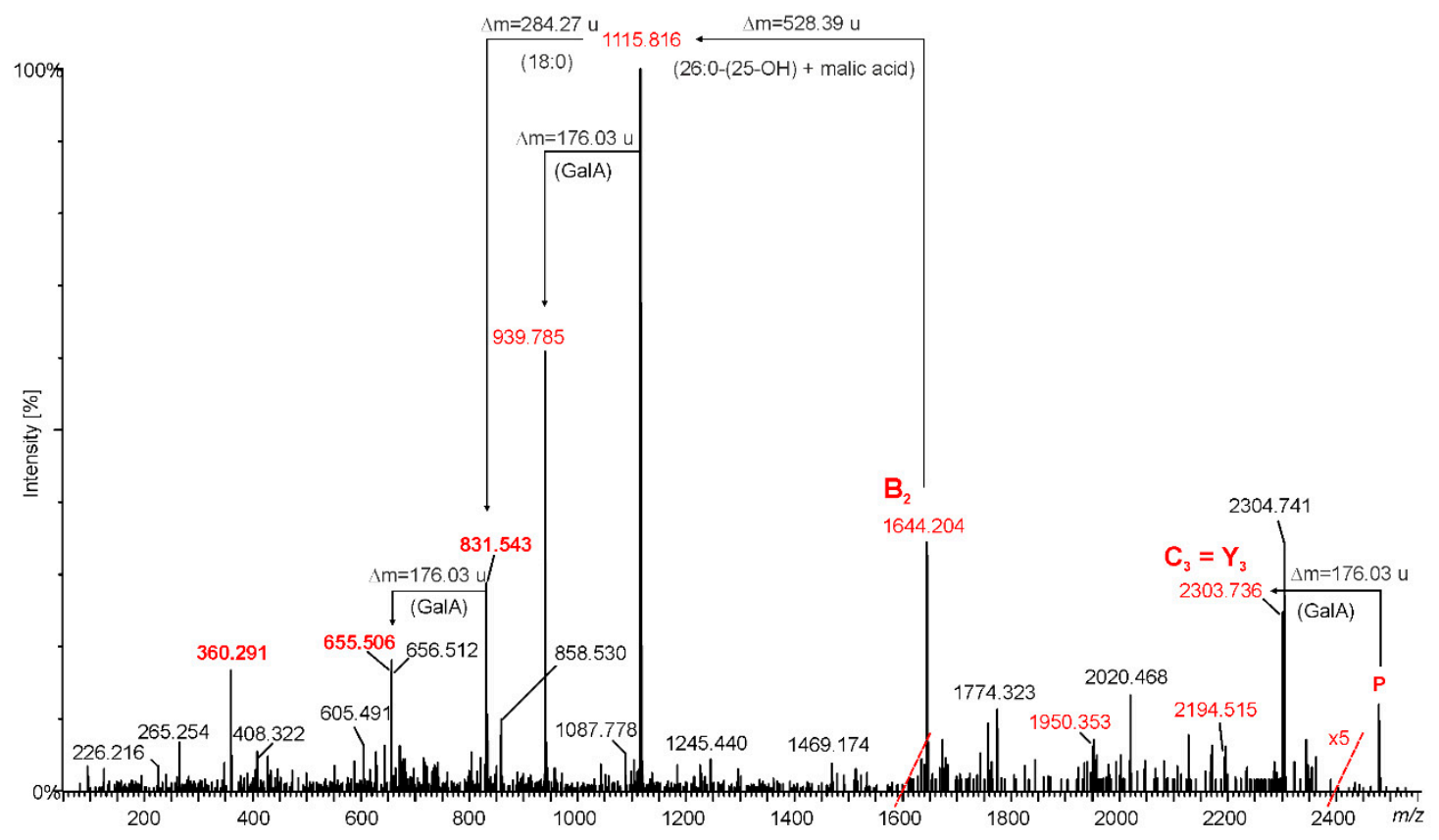

Figure 4. MALDI-TOF MS/MS spectrum of the parent ion at $m / z 2478.775$ (heptaacylated lipid A of O. carboxidovorans). Peaks between $\mathrm{m} / \mathrm{z} 1600$ and 2400 are magnified five times. Ions marked in red are discussed in the text.

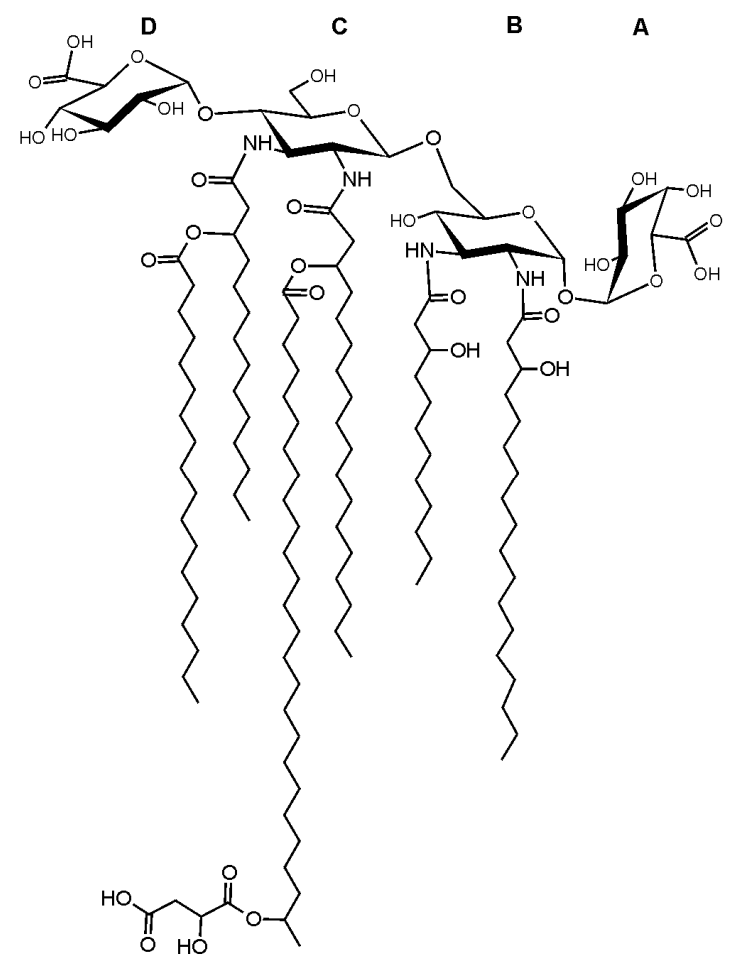

Figure 5. Proposed structural formula for the most complex O. carboxidovorans OM5 lipid A molecule. $\mathrm{M}_{\mathrm{mi}}=2455.76435 \mathrm{u}$.

\subsection{Genomic Studies}

The experimental data showing the structure of O. carboxidovorans OM5 lipid A obtained with MALDI-TOF mass spectrometry and NMR spectroscopy were further supplemented by in silico 
analyses of the O. carboxidovorans OM5 genomic sequence aiming to identify putative genes encoding proteins/enzymes engaged in the lipid A biosynthesis pathway.

The sequence similarity of the $16 \mathrm{~S}$ rRNA gene indicates that $O$. carboxidovorans is closely related to the members of the Bradyrhizobiaceae family [6]. Our results thereby confirm that the structure of the O. carboxidovorans lipid A sugar backbone is identical to that of Aquifex pyrophilus [20] and Caulobacter crescentus [21]. In turn, at its reducing end, it resembles some mesorhizobial lipids A (i.e., M. huakuii IFO 15243T and M. loti MAFF303099) [10,11]. Moreover, at the non-reducing end, it resembles some rhizobial lipids A [9]. The lipid A structure as well as gene clusters engaged in its biosynthesis have been recognized for M. loti MAFF303099 and Rhizobium leguminosarum 3841; therefore, respective protein sequences of these model strains were used as queries in BLAST similarity searches comprising the O. carboxidovorans OM5 genome sequence (Table 4). Using this approach, we recognized a set of putative genes coding for common enzymes required for the lipid A biosynthesis (i.e., $l p x A-D, l p x H$, $l p x K$, and $k d t A$, data for these genes are not shown) and genes encoding specific enzymes involved in the structural modifications of lipid A ( $l p x E, l p x F, r g t D, r g t F, r g t E$ and $a c p X L-l p x X L$ cluster) found in some Gram-negative bacteria (Tables 4 and 5). Additionally, using M. loti, lipid A biosynthesis related proteins as queries in the genome of $O$. carboxidovorans sequences coding for putative enzymes involved in the conversion of Glc $p$ N to Glc $p$ N3N (presumable homologs of $g n n A$ and $g n n B$ ) were identified (Table 5). Such enzymes, essential for the biosynthesis of the Glc $p$ N3N type of the lipid A disaccharide backbone, are specific not only for Mesorhizobium but also for the Azorhizobium and Bradyrhizobium genera. Putative ORFs detected in the O. carboxydovorans OM5 genome ascribed to lipid A biosynthesis/modification shared sequence similarity with the respective proteins of $M$. loti MAFF 303099 or R. leguminosarum bv. Viaciae 3841 (reaching even 78\% for individual proteins encoded in the acpXL-lpxXL cluster) (Tables 4 and 5), strongly suggesting their engagement in this biosynthetic pathway. Due to the identical structures of the sugar part of lipid A of O. carboxidovorans OM5 and Aquifex pyrophilus, the database searches aiming to identify putative genes necessary for Glc $p$ N3N-(1 $\rightarrow 6)-G l c p N 3 N$ backbone biosynthesis were extended to representatives of Aquifex and Caulobacter. In the Aquifex genus, Aquifex aeolicus VF5 is the only accessible fully sequenced genome (lack of genomic data for A. pyrophilus). In the A. aeolicus VF5 genome, putative homologues of the $\operatorname{rg} t D, \operatorname{rgt} F$, and $\operatorname{rg} t E$ genes were identified (Table 4). Surprisingly, we were not able to detect sequences similar to $l p x E$ and $l p x F$ (encoding hypothetical lipid A phosphatases) in the A. aeolicus VF5 genome. These enzymes were shown to be involved in dephosphorylation of the lipid A precursor during the biosynthesis of LPS in R. leguminosarum bv. Viciae 3841 [11]. It may be assumed that the process of phosphate residue removal from both ends of the Glc $p$ N3N-disaccharide in representatives of the Aquifex genus is catalyzed by other types of unknown phosphatases.

As demonstrated by previously published structural data for lipid A of Caulobacter crescentus CB15 [21], putative homologues of $l p x E, r g t D, r g t F$, and $r g t E$ were found in its genome (Table 4). In the reference genomes, the rgtDFE genes encode hypothetical $4^{\prime}-\alpha-G a l p A, \alpha-(1 \rightarrow 1)-G a l p A$, and bactoprenyl-phosphate-GalpA transferases, respectively [11]. The C. crescentus CB15 ORF marked as CC_3019 displayed some sequence similarity with putative lipid A 1-phosphatase encoded by lpxE in R. leguminosarum bv. Viciae 3841 [22]. However, using this approach, no putative homologues of lipid A 4'-phosphatase were found in the C. crescentus CB15 genome. In Aquifex, Azorhizobium (data not shown), Mesorhizobium, and Oligotropha homologues of $r \operatorname{tg} E$ and $r \operatorname{tg} F$ are clustered; however, it seems not to be a prerequisite for respective protein products to participate effectively in lipid A modification (see R. leguminosarum, Table 4). On the other hand, the available data strongly suggest that genes responsible for the synthesis and incorporation of VLCFAs into lipid A always form a tight cluster [9]. Although a set of genes presumably engaged in VLCFA production was found in C. crescentus CB15 (Table 5), they were dispersed over the bacterial genome, and the formation and incorporation of VLCFAs was not observed in these bacteria. 
Table 4. Sequence similarity of putative proteins involved in lipid A modification in Oligotropha carboxidovorans OM5, Aquifex aeolicus and Caulobacter crescentus CB15 with enzymes of known functions from the reference strains: Rhizobium leguminosarum bv. Viciae 3841 and Mesorhizobium loti MAFF303099).

\begin{tabular}{|c|c|c|c|c|c|}
\hline $\begin{array}{c}\text { Gene Name } \\
\text { (Putative Protein Function) }\end{array}$ & $\begin{array}{c}\text { lpxE } \\
\text { (Lipid A 1-Phosphatase) }\end{array}$ & $\begin{array}{c}\operatorname{lpxF} \\
\text { (Lipid A 4'-Phosphatase) }\end{array}$ & $\begin{array}{c}r g t D \\
\left(4^{\prime}-\text { GalA Transferase) }\right.\end{array}$ & $\begin{array}{c}\text { rgtF } \\
(\alpha-(1,1)-G a l A \\
\text { Transferase) }\end{array}$ & $\begin{array}{c}\operatorname{rgtE} \\
\text { (Bactoprenyl/Phosphate } \\
\text { GalA Transferase) }\end{array}$ \\
\hline $\begin{array}{l}\text { Reference sequence of: } R \text {. leguminosarum } \\
3841 \text { and/or M. loti MAFF303099 }\end{array}$ & RL_RS24225 (RL4708) & RL_RS08140 (RL1570) & RL_RS03600 (RL0684) & $\begin{array}{l}\text { MAFF_RS01135 }{ }^{2} \\
\text { (mlr0011) }\end{array}$ & RL_RS07630 (RL1470) \\
\hline O. carboxidovorans OM5 & OCA5_c19740 & OCA5_cRS09935 & OCA5_RS09935 & OCA5_c19750 & OCA5_c19730 \\
\hline$\%$ Identity $^{1}$ & 31.97 & 30.96 & 28.81 & 39.28 & 34.69 \\
\hline Aquifex aeolicus VF5 & ND & ND & aq_765 & aq_1695a & aq_1899 \\
\hline $\begin{array}{l}\quad \% \text { Identity }{ }^{1} \\
\text { Caulobacter crescentus (vibroides) CB15 }\end{array}$ & IND & No & 29.31 & 22.73 & 39.82 \\
\hline $\begin{array}{l}\text { Caulobacter crescentus (vibroides) CB15 } \\
\% \text { Identity } 1\end{array}$ & $\begin{array}{c}\text { CC_301S } \\
29.84\end{array}$ & ND & $\begin{array}{c}\text { CC_0209 } \\
31.66\end{array}$ & $\begin{array}{c}\text { CC_0468 } \\
33.27\end{array}$ & $\begin{array}{c}\text { CC_0469 } \\
33.33\end{array}$ \\
\hline $\begin{array}{l}\text { Putative function ascribed on BLAST } \\
\text { sequence similarity }\end{array}$ & $\begin{array}{l}\text { phosphatase PAP2 } \\
\text { family protein }\end{array}$ & $\begin{array}{c}\text { phosphoesterase } \\
\text { PA-phosphatase related }\end{array}$ & $\begin{array}{l}\text { dolichyl-phosphate-mannose-protein } \\
\text { mannosyltransferase }\end{array}$ & glycosyl transferase & $\begin{array}{l}\text { glycosyl transferase, } \\
\text { family } 2\end{array}$ \\
\hline
\end{tabular}

$1 \%$ Identity with reference sequence. ${ }^{2}$ R. leguminosarum bv. Viciae 3841 synthetize lipid A without GalA connected to proximal GlcN [9] and gene coding for $\alpha$-(1,1)-GalA transferase is not present in its genome. Therefore, respective coding sequence mlr0011 from M. loti MAFF303099 [11] was used as reference in similarity searches.

Table 5. Sequence similarity of putative proteins involved in lipid A modification in Oligotropha carboxidovorans OM5 and Caulobacter crescentus CB15 with enzymes of known functions from the reference strains: Mesorhizobium loti MAFF303099 and Sinorhizobium meliloti 1021.

\begin{tabular}{|c|c|c|c|c|c|c|c|c|}
\hline $\begin{array}{c}\text { Gene Name } \\
\text { (Putative Protein Function) }\end{array}$ & $\begin{array}{c}g n n A \\
\text { (NAD-Dependent } \\
\text { Oxidation of GlcN } \\
\text { 3-OH of } \\
\text { UDP-GlcNAc) } \\
\end{array}$ & $\begin{array}{c}g n n B \\
\text { (Transamination to } \\
\text { Form } \\
\text { UDP-GlcNAc3N) }\end{array}$ & $\begin{array}{c}a c p X L \\
\text { (Acyl Carrier } \\
\text { Protein) }\end{array}$ & $\begin{array}{c}f a b Z X L \\
\text { (3R)-Hydroxyacyl-ACP } \\
\text { Dehydratase }\end{array}$ & $\begin{array}{c}f a b F 2 X L \\
\text { (Beta-Ketoacyl-ACP } \\
\text { Synthase) }\end{array}$ & $\begin{array}{c}f a b F 1 X L \\
\text { (Beta-Ketoacyl-ACP } \\
\text { Synthase) }\end{array}$ & $\begin{array}{c}a d h 2 X L \\
\text { (Zinc-Binding } \\
\text { Dehydrogenase) }\end{array}$ & $\begin{array}{c}\text { lpxXL }(m s b B) \\
\text { (VLCFA Acyltransferase } \\
\text { to C2' Position of Lipid A) }\end{array}$ \\
\hline $\begin{array}{l}\text { Reference sequence of M. loti } \\
\text { MAFF303099 and/or S. meliloti } \\
1021 \\
\text { (old description) }\end{array}$ & $\underset{(m)}{\text { MAFF_RS121282I) }}$ & $\begin{array}{l}\text { MAFF_RS30880 } \\
(m \text { mll7579) }\end{array}$ & $\begin{array}{c}\text { MAFF_RS05885 } \\
(\text { mlrn1174) }\end{array}$ & $\begin{array}{l}\text { SM_RS09960 } \\
(S M c 04277)^{2}\end{array}$ & $\begin{array}{l}\text { MAFF_RS05890 } \\
\quad(m \text { llr1176) }\end{array}$ & $\underset{(m l r 1177)}{\text { MAFF_RS05895 }}$ & $\underset{(m l r 1178)}{\text { MAFF_RS05900 }}$ & $\underset{(m l r 1179)}{\text { MAFF_RS05905 }}$ \\
\hline $\begin{array}{l}\text { (old description) } \\
\text { Oligotropha carboxydovorans OM5 } \\
\text { (DSM1227) } \\
\text { \% Identity }{ }^{1}\end{array}$ & $\begin{array}{c}\text { OCA5_c26370 } \\
32.37\end{array}$ & $\begin{array}{c}\text { OCA5_c26360 } \\
55.41\end{array}$ & $\begin{array}{c}a c p X L \\
78.49\end{array}$ & $\begin{array}{l}f a b A \\
50.34\end{array}$ & $\begin{array}{c}\text { OCA5_c15570 } \\
43.59\end{array}$ & $\begin{array}{l}f a b F 1 \\
58.12\end{array}$ & $\begin{array}{l}\text { OCA5_c15550 } \\
62.24\end{array}$ & $\begin{array}{c}\text { OCA5_c15540 } \\
38.36\end{array}$ \\
\hline $\begin{array}{c}\text { Caulobacter crescentus CB15 } \\
\text { \% Identity }^{1}\end{array}$ & $\begin{array}{l}\text { CC_1225 } \\
25.29\end{array}$ & $\begin{array}{l}\text { CC_3611 } \\
53.12\end{array}$ & $\begin{array}{l}\text { CC_1677 } \\
39.29\end{array}$ & $\begin{array}{c}\text { CCNA_01989 } \\
36.59\end{array}$ & $\begin{array}{l}\text { CC_1678 } \\
23.76\end{array}$ & $\begin{array}{c}\text { CC_1678 } \\
31.54 \\
\text { CC-3719 } \\
30\end{array}$ & $\begin{array}{l}\text { CC_1569 } \\
30.41\end{array}$ & $\begin{array}{l}\text { CC_2250 } \\
32.26\end{array}$ \\
\hline $\begin{array}{l}\text { Putative function ascribed on } \\
\text { BLAST sequence similarity }\end{array}$ & $\begin{array}{l}\text { oxidoreductase } \\
\text { domain protein }\end{array}$ & $\begin{array}{l}\text { DegT/DnrJ/EryC1/StrS } \\
\text { aminotransferase }\end{array}$ & $\begin{array}{c}\text { acyl carrier } \\
\text { protein AcpXL }\end{array}$ & $\begin{array}{c}\text { beta-hydroxyacylACP } \\
\text { dehydratase }\end{array}$ & beta-ketoacyl synthase & $\begin{array}{l}\text { 3-oxoacyl-[ACP] } \\
\text { synthase } 2\end{array}$ & $\begin{array}{c}\text { alcohol } \\
\text { dehydrogenase }\end{array}$ & $\begin{array}{l}\text { VLCFA acyltransferase to } \\
\text { C2' position of lipid A }\end{array}$ \\
\hline
\end{tabular}

$1 \%$ Identity with reference sequence. ${ }^{2} M$. loti MAFF303099 synthetize VLCFAs using housekeeping FabZ and region in M. loti genome encoding enzymes responsible for VLCFAs

biosynthesis does not contain fabZXL homolog. Therefore, respective coding sequence SMc04277 from S. meliloti 1021 was used as reference in similarity searches [9]. 


\section{Discussion}

In this work, we have described the structure of O. carboxidovorans OM5 lipid A, which contains a $\beta$-D-Glc $p$ N3N-(1 $\rightarrow 6)-\alpha$-D-Glc $p$ N3N disaccharide decorated on both sides (at positions C- 1 and C-4') by $\alpha$-D-GalpA residues. This extended sugar backbone is unique in bacteria. To date, there have been only two reports of the existence of similar lipids A. They are synthesized by bacteria belonging to the hypertermophilic Aquifex pyrophilus species [20], and the stalk-forming Caulobacter crescentus [21]. The substitution of only the reducing end of lipid A by $\alpha-(1 \rightarrow 1)-\mathrm{D}-\mathrm{Gal} p \mathrm{~A}$ is also not common among bacteria and has been identified in lipids A from a few representative genera. These include the associative diazotroph Azospirillum lipoferum [23], and some rhizobia: M. huakuii [10], M. loti [11], and P. trifolii [24]. On the other hand, the substitution of exclusively the non-reducing end of lipid A by $\alpha$-D-GalpA- $\left(1 \rightarrow\right.$ at position C- $4^{\prime}$ is not common either, and has been identified in lipids A from a few representatives of rhizobia (R. etli CE3, R. leguminosarum bvs. Trifolii and Viciae) [9].

The amino groups of both Glc $p$ N3N of $O$. carboxidovorans OM5 lipid A are symmetrically substituted by 3-hydroxyoctadecanoic fatty acid at position C-2 and C-2'. In the dominant type of lipid A molecules, the amino group at position C-3 is acylated with 3-hydroxylauric acid, while a 3-hydroxymyristoyl group is located at position C-3'. Due to the multiplicity of signals assigned to heptaacylated lipid $\mathrm{A}$, another distribution of primary fatty acids in individual subgroups of lipid A molecules should also be expected. Even if the extended backbones of lipids A synthesized by Oligotropha, Aquifex, and Caulobacter are the same, the substituting primary fatty acids are significantly different. Lipid A contains mainly 18:0(3-OH) (or 14:0(3-OH) and 12:0(3-OH)):residues in Oligotropha, 16:0(3-OH) (and 14:0(3-OH)) residues in Aquifex, and almost exclusively 12:0(3-OH) residues in Caulobacter. This fact can be explained by the different basic metabolisms of fatty acids of these bacteria $[7,25,26]$.

The 28:0(27-OH) fatty acid is the most often isolated VLCFA-type fatty acid among rhizobia [27], but the 26:0(25-OH) fatty acid took its place in Oligotropha. In addition, 25-hydroxyhexacosanoic acid was almost totally acylated with a malic acid residue. It should be emphasized that this type of tertiary substituent has not been described in the literature so far. Since ester-linked fatty acids (18:0 and 26:0(25-OH) are secondary substituents of the distal Glc $p$ N3N, the complete lipid A is asymmetrically acylated and resembles the E. coli lipid A pattern denoted by formula $4+2$ (or more precisely $5+2$ ) [28].

We have found structural similarities in the acylation of lipid A with VLCFA between O. carboxidovorans and some rhizobia. Moreover, we have shown that the sugar backbone of lipid A in O. carboxidovorans is the same as in A. pyrophilus and C. crescentus. Additionally, structural similarities among the sugar backbones of lipid A of O. carboxidovorans, M. loti, R. leguminosarum, and P. trifolii, were shown. These observations were confirmed at the genomic level. Putative ORFs predicted for the lipid A biosynthesis pathway in Oligotropha shared sequence similarity with corresponding proteins of reference microorganisms. Further genetic and biochemical studies are necessary to elucidate which putative enzymes and at which stage of biosynthesis are involved in the esterification of the hydroxyl group of VLCFA by malic acid. This issue (on tertiary acyls) remains unexplored for all rhizobial lipids A.

\section{Materials and Methods}

\subsection{Bacterial Strain and Culture Condition}

Oligotropha carboxidovorans strain OM5 (type strain, DSM 1227; previously known as Pseudomonas carboxydovorans OM5) was obtained from the DSMZ culture collection (Leibniz-Institute, Braunschweig, Germany). The bacteria were cultivated in aerobic conditions, in a CMO (carbon monoxide oxidizer) medium containing $0.3 \%$ sodium acetate as a carbon source, at $30^{\circ} \mathrm{C}$, with aeration by vigorous shaking.

\subsection{LPS and Lipid A Isolation and Purification}

LPS was isolated from previously delipidated and enzymatically digested cells, using the hot $45 \%$ phenol/water extraction method [17,18], as described by Komaniecka and co-workers [29]. The LPS 
was obtained after ultracentrifugation $\left(104,000 \times g, 4 \mathrm{~h}, 4^{\circ} \mathrm{C}\right)$. It was found mainly in the water phase (90\%). The lipid A was liberated from the LPS by mild acid hydrolysis of $210 \mathrm{mg}$ of LPS using 1\% acetic acid $\left(3 \mathrm{~h}, 100^{\circ} \mathrm{C}\right)$. After cooling in an ice bath, the hydrolysate was converted to the two-phase Bligh-Dyer system containing chloroform/methanol/water (2:2:1.8, $v / v / v)$, and the resulting water and organic phases were separated by centrifugation $\left(4000 \times g, 15 \mathrm{~min}, 20^{\circ} \mathrm{C}\right)[30,31]$. The organic phase containing a lipid A portion was collected, washed twice with a water phase from the freshly prepared two-phase Bligh-Dyer system, and evaporated to dryness. Crude lipid A was stored at $-20{ }^{\circ} \mathrm{C}$ as a solution in chloroform/methanol (3:1, v/v).

\subsection{Sugar and Fatty Acid Analysis}

The sugar composition of lipid A was established by hydrolysis with $2 \mathrm{M}$ trifluoroacetic acid $\left(100{ }^{\circ} \mathrm{C}, 4 \mathrm{~h}\right)$ and conversion of liberated monosaccharides into (amino)alditol acetates [32]. Fatty acids were analyzed after acid hydrolysis $\left(4 \mathrm{M} \mathrm{HCl}_{\mathrm{aq}}, 100^{\circ} \mathrm{C}, 4 \mathrm{~h}\right)$, extraction with chloroform $(1: 1, v / v)$, and methanolysis $\left(0.5 \mathrm{M} \mathrm{HCl} / \mathrm{methanol}, 85^{\circ} \mathrm{C}, 2 \mathrm{~h}\right)$. Liberated hydroxy fatty acids were converted to trimethylsilyl (TMSi) derivatives of their methyl esters. Fatty acids and volatile components of lipid A obtained after methanolysis $\left(2 \mathrm{M} \mathrm{HCl} /\right.$ methanol, $85^{\circ} \mathrm{C}, 18 \mathrm{~h}$ ) were converted to butyl esters by weak butanolysis $\left(1 \mathrm{M} \mathrm{HCl} / \mathrm{butanol}, 65^{\circ} \mathrm{C}, 2 \mathrm{~h}\right)$ and TMSi derivatized. All preparations were analyzed by GC-MS using the Agilent Technologies GC System 7890A connected to a mass selective detector (inert XL EI/CI MSD 5975C) equipped with a HP-5MS column (30 $\mathrm{m} \times 0.25 \mathrm{~mm}$ ). Helium was a carrier gas with a flow rate of $1 \mathrm{~mL} \mathrm{~min}^{-1}$. The temperature program for sugar analysis was as follows: $150{ }^{\circ} \mathrm{C}$ for $5 \mathrm{~min}$, raised to $310{ }^{\circ} \mathrm{C}$ at $5^{\circ} \mathrm{C} \cdot \mathrm{min}^{-1}$, and the final temperature was kept for $10 \mathrm{~min}$. For analysis of fatty acid derivatives, the ramp of the temperature gradient was established at $10{ }^{\circ} \mathrm{C} \cdot \mathrm{min}^{-1}$. The temperature program for volatile components was as follows: $50{ }^{\circ} \mathrm{C}$ for $5 \mathrm{~min}$, raised to $310^{\circ} \mathrm{C}$ at $5^{\circ} \mathrm{C} \cdot \mathrm{min}^{-1}$, and the final temperature was kept for $5 \mathrm{~min}$.

\subsection{NMR Spectroscopy}

For the NMR analysis, the native lipid A was dissolved in the mixture of chloroform-d1/methanol-d4 $(6: 1, v / v) .1 \mathrm{D}$ and 2D NMR spectra (homonuclear: ${ }^{1} \mathrm{H},{ }^{1} \mathrm{H}$ COSY, TOCSY, ROESY; and heteronuclear: ${ }^{1} \mathrm{H}^{13} \mathrm{C}$ HSQC, HSQC-TOCSY, and HMBC) were recorded using a Bruker Avance III $700 \mathrm{MHz}$ spectrometer at $25^{\circ} \mathrm{C}$. Data were analyzed using TopSpin 3.2 (Bruker) software. Proton and carbon chemical shifts were measured in relation to the TMS as an internal standard $\left(\delta_{\mathrm{H}} 0.00, \delta_{\mathrm{C}} 0.0\right)$.

\subsection{Mass Spectrometry}

MALDI-TOF mass spectrometry was performed with a SYNAPT G2-Si HDMS instrument (Waters Corporation, Milford, MA, USA) equipped with a $1 \mathrm{KHz}$ Nd:YAG laser system (355 nm wavelength). Acquisition of the data was performed using MassLynx software version 4.1 SCN916 (Waters Corporation, Wilmslow, UK). Mass spectra were assigned with a multi-point external calibration using red phosphorous (Sigma). The lipid A samples were dissolved in chloroform/methanol (3:1, $v / v)$ at a concentration of $10 \mu \mathrm{g} / \mu \mathrm{L}$, and $2 \mathrm{mM}$ of EDTA was added. A sample $(1 \mu \mathrm{L})$ was transferred into the target plate wells covered with a thin matrix film. The matrix solution was prepared from $2^{\prime}, 4^{\prime}, 6^{\prime}$-trihydroxyacetophenone (THAP) $(200 \mathrm{mg} / \mathrm{ml}$ in methanol) and mixed with nitrocellulose (NC) $(15 \mathrm{mg} / \mathrm{ml}$, suspended in 2-propanol/acetone $(1: 1, v / v))$ in a proportion of $4: 1(v / v)$, as previously described by Silipo and co-workers [33]. Spectra were recorded in positive and negative ion modes.

\subsection{Bioinformatics Analysis}

Standard BLAST setting (with the cut-off E-value of $10^{-5}$ ) was used in searching for putative proteins engaged in the biosynthetic pathway of Oligotropha lipid A. Protein sequences of M. loti MAFF 303099 and R. leguminosarum 3841 were used as queries in the TBLASTN searches against a genomic sequence of the O. carboxidovorans OM5 strain registered in the NCBI online Database. Individual BLAST protein subjects were then compared across their entire span with reference sequences using 
an online Global Alignment tool (with the Needleman-Wunsch algorithm) provided by the National Center for Biotechnology Information (NCBI).

Author Contributions: Conceptualization, A.C. and I.K.; methodology, A.C., A.M., and I.K.; experiments, K.Z., A.P., Z.K., and I.K.; writing-original draft preparation, A.C. and I.K.; writing-review and editing, A.C. and I.K. All authors have read and agreed to the published version of the manuscript.

Funding: This research received no external funding.

Acknowledgments: The spectrometer Waters SYNAPT 2G-Si HDMS was purchased from the European Union Funds, Operational Program Infrastructure and Environment (project number: UDA-POIiS.13.01-045/08).

Conflicts of Interest: The authors declare no conflict of interest.

\section{Abbreviations}

$\begin{array}{ll}\text { EDTA } & \text { ethylenediaminetetraacetic acid } \\ \text { Glc } p \text { N3N } & \text { 2,3-diamino-2,3-dideoxyglucose } \\ \text { Gal } p \text { A } & \text { galacturonic acid } \\ \text { MALDI-TOF } & \text { matrix assisted laser desorption/ionization-time of flight } \\ \text { NC } & \text { nitrocellulose } \\ \text { std } & \text { internal standard } \\ \text { Sug } & \text { sugar residue } \\ \text { THAP } & 2^{\prime}, 4^{\prime}, 6^{\prime} \text {-trihydroxyacetophenone } \\ \text { TMSi } & \text { trimethylsilylating reagent } \\ \text { VLCFA } & \text { very long chain fatty acid }\end{array}$

\section{References}

1. Meyer, O.; Schlegel, H.G. Reisolation of the carbon monoxide utilizing hydrogen bacterium Pseudomonas carboxydovorans (Kistner) comb. nov. Arch. Microbiol. 1978, 118, 35-43. [CrossRef] [PubMed]

2. Meyer, O.; Stackebrandt, E.; Auling, G. Reclassification of ubiquinone Q-10 containing carbooxidotrophic bacteria: Transfer of "[Pseudomonas] carboxydovorans" $\mathrm{OM} 5^{\mathrm{T}}$ to Oligotropha, gen. nov., as Oligotropha carboxidovorans, comb. nov., transfer of "[Alcaligenes] carboxydus" DSM 1086 ${ }^{\mathrm{T}}$ to Carbophilus, gen. nov., as emphCarbophilus carboxidus, comb. nov., transfer of "[Pseudomonas] compransoris" DSM $1231^{\mathrm{T}}$ to Zavarzinia, gen. nov., as Zavarzinia compransoris, comb. nov., amended description of the new genera. Syst. Appl. Microbiol. 1993, 16, 390-395.

3. Meyer, O.; Schlegel, H.G. Biology of aerobic carbon monoxide-oxidizing bacteria. Annu. Rev. Microbiol. 1983, 37, 277-310. [CrossRef] [PubMed]

4. Fuhrmann, S.; Ferner, M.; Jefke, T.; Henne, A.; Gottschalk, G.; Meyer, O. Complete nucleotide sequence of the circular megaplasmid pHCG3 of Oligotropha carboxidovorans: Function in the chemolithoautotrophic utilization of $\mathrm{CO}, \mathrm{H}(2)$ and $\mathrm{CO}(2)$. Gene 2003, 322, 67-75. [CrossRef] [PubMed]

5. Hille, R.; Dingwall, S.; Wilcoxen, J. The aerobic CO dehydrogenase from Oligotropha carboxidovorans. J. Biol. Inorg. Chem. 2015, 20, 243-251. [CrossRef]

6. Paul, D.; Bridges, S.S.; Burgess, S.C.; Dandass, Y.S.; Lawrence, M.L. Complete genome and comparative analysis of the chemolithoautotrophic bacterium Oligotropha carboxidovorans OM5. BMC Genom. 2010, 11, 511. [CrossRef]

7. Paul, D.; Kumar, R.; Nanduri, B.; French, T.; Pendarvis, K.; Brown, A.; Lawrence, M.L.; Burgess, S.C. Proteome and membrane fatty acid analyses on Oligotropha carboxidovorans OM5 grown under chemolithoautotrophic and heterotrophic conditions. PLOS ONE 2011, 6, e17111. [CrossRef]

8. Malik, A.; Kakii, K. Intergeneric coaggregations among Oligotropha carboxidovorans and Acinetobacter species present in activated sludge. FEMS Microbiol. Lett. 2003, 224, 23-28. [CrossRef]

9. Choma, A.; Komaniecka, I.; Żebracki, K. Structure, biosynthesis and function of unusual lipids A from nodule-inducing and $\mathrm{N}_{2}$-fixing bacteria. Biochim. Biophys. Acta 2017, 1862, 196-209. [CrossRef]

10. Choma, A.; Sowinski, P. Characterization of Mesorhizobium huakuii lipid A containing both D-galacturonic acid and phosphate residues. Eur J Biochem. 2004, 271, 1310-1322. [CrossRef] 
11. Brown, D.B.; Muszynski, A.; Carlson, R.W. Elucidation of a novel lipid A $\alpha$-(1,1)-GalA transferase gene $(r g t F)$ from Mesorhizobium loti: Heterologous expression of rgtF causes Rhizobium etli to synthesize lipid A with $\alpha$-(1,1)-GalA. Glycobiology 2013, 23, 546-558. [CrossRef] [PubMed]

12. Komaniecka, I.; Choma, A.; Lindner, B.; Holst, O. The structure of a novel neutral lipid A from the lipopolysaccharide of Bradyrhizobium elkanii containing three mannoses units in the backbone. Chem. Eur. J. 2010, 16, 2922-2929. [CrossRef]

13. Komaniecka, I.; Choma, A.; Mazur, A.; Duda, K.A.; Lindner, B.; Schwudke, D.; Holst, O. Occurrence of an unusual hopanoid-containing lipid A among lipopolysaccharides from Bradyrhizobium species. J. Biol. Chem. 2014, 289, 35644-35655. [CrossRef] [PubMed]

14. Silipo, A.; Vitiello, G.; Gully, D.; Sturiale, L.; Chaintreuil, C.; Fardoux, J.; Gargani, D.; Lee, H.I.; Kulkarni, G.; Busset, N.; et al. Covalently linked hopanoid-lipid A improves outer membrane resistance of a Bradyrhizobium symbiont of legumes. Nat. Commun. 2014, 5, 5106. [CrossRef] [PubMed]

15. Mayer, H.; Krauss, J.H.; Urbanik-Sypniewska, T.; Puvanesarajah, V.; Stacey, G.; Auling, G. Lipid A with 2,3-diamino-2,3-dideoxy-glucose in lipopolysaccharides from slow-growing members of Rhizobiaceae and from "Pseudomonas carboxydovorans". Arch. Microbiol. 1989, 151, 111-116. [CrossRef]

16. Volland, S.; Rachinger, M.; Strittmatter, A.; Daniel, R.; Gottschalk, G.; Meyer, O. Complete genome sequences of the chemolithoautotrophic Oligotropha carboxidovorans strains OM4 and OM5. O. J. Bacteriol. 2011, 193, 5043. [CrossRef] [PubMed]

17. Westphal, O.; Jann, K. Bacterial lipopolysaccharide. Extraction with phenol-water and further application of the procedure. In Methods in Carbohydrate; Whistler, R.L., Ed.; Academic Press: Cambridge, MA, USA, 1965; Volume 5, pp. 83-91.

18. Johnson, K.G.; Perry, M.B. Improved techniques for the preparation of bacterial lipopolysaccharides. Can. J. Microbiol. 1976, 22, 29-34. [CrossRef]

19. Domon, B.; Costello, C. A systematic nomenclature for carbohydrate fragmentations in FAB-MS/MS spectra of glycoconjugates. Glycoconjugate J. 1988, 5, 397-409. [CrossRef]

20. Plötz, B.M.; Lindner, B.; Stetter, K.O.; Holst, O. Characterization of a novel lipid A containing D-galacturonic acid that replaces phosphate residues. The structure of the lipid a of the lipopolysaccharide from the hyperthermophilic bacterium Aquifex pyrophilus. J. Biol. Chem. 2000, 275, 11222-11228.

21. Smit, J.; Kaltashov, J.A.; Cotter, R.J.; Vinogradov, E.; Perry, M.B.; Haider, H.; Qureshi, N. Structure of a novel lipid A obtained from the lipopolysaccharide of Caulobacter crescentus. Innate Immun. 2008, 14, $25-37$. [CrossRef]

22. Karbarz, M.J.; Six, D.A.; Raetz, C.R. Purification and characterization of the lipid A 1-phosphatase LpxE of Rhizobium leguminosarum. J. Biol. Chem. 2009, 284, 414-425. [CrossRef] [PubMed]

23. Choma, A.; Komaniecka, I. Characterization of a novel lipid A structure isolated from Azospirillum lipoferum lipopolysaccharide. Carbohydr. Res. 2008, 343, 799-804. [CrossRef] [PubMed]

24. Zamlynska, K.; Komaniecka, I.; Zebracki, K.; Mazur, A.; Sroka-Bartnicka, A.; Choma, A. Studies on lipid A isolated from Phyllobacterium trifolii PETP02T lipopolysaccharide. Ant. Leeuwen. 2017, 110, 1413-1433. [CrossRef]

25. Jahnke, L.L.; Eder, W.; Huber, R.; Hope, J.M.; Hinrichs, K.-U.; Hayes, J.M.; Des Marais, D.J.; Cady, S.L.; Summons, R.E. Signature lipids and stable carbon isotope analyses of Octopus Spring hyperthermophilic communities compared with those of Aquificales representatives. Appl. Environ. Microbiol. 2001, 67, 5179-5189. [CrossRef] [PubMed]

26. Letts, V.; Shaw, P.; Shapiro, L.; Henry, S. Synthesis and utilization of fatty acids by wild-type and fatty acid auxotrophs of Caulobacter crescentus. J. Bacteriol. 1982, 151, 1269-1278. [CrossRef]

27. Bhat, U.R.; Mayer, H.; Yokota, A.; Hollingsworth, R.I.; Carlson, R.W. Occurrence of lipid A variants with 27-hydroxyoctacosanoic acid in lipopolysaccharides from members of the family Rhizobiaceae. J. Syst. Bacteriol. 1991, 173, 2155-2159. [CrossRef]

28. Raetz, C.R.H.; Whitfield, C. Lipopolisaccharide endotoxins. Annu. Rev. Biochem. 2002, 71, 635-700. [CrossRef]

29. Komaniecka, I.; Choma, A.; Zamlynska, K.; Sroka-Bartnicka, A.; Sowinski, P. Structure of O-specific polysaccharide of Oligotropha carboxidovorans OM5-A wastewater bacterium. Carbohydr. Res. 2017, 439, 30-34. [CrossRef] 
30. Que, N.L.S.; Lin, S.H.; Cotter, R.J.; Raetz, C.R.H. Purification and mass spectrometry of six lipid A species from the bacterial endosymbiont Rhizobium etli-Demonstration of a conserved distal unit and a variable proximal portion. J. Biol. Chem. 2000, 275, 28006-28016. [CrossRef]

31. Choma, A.; Komaniecka, I.; Turska-Szewczuk, A.; Danikiewicz, W.; Spolnik, G. Structure of lipid A from a stem-nodulating bacterium Azorhizobium caulinodans. Carbohydr. Res. 2012, 352, 126-136. [CrossRef]

32. Sawardeker, J.S.; Sloneker, J.H.; Jeanes, A.R. Quantitative determination of monosaccharides as their alditol acetates by gas liquid chromatography. Anal. Chem. 1965, 37, 1602-1604. [CrossRef]

33. Silipo, A.; Molinaro, A.; Sturiale, L.; Dow, J.M.; Erbs, G.; Lanzetta, R.; Newman, M.A.; Parrilli, M. The elicitation of plant innate immunity by lipooligosaccharide of Xanthomonas campestris. J. Biol. Chem. 2005, 280, 33660-33668. [CrossRef] [PubMed]

Publisher's Note: MDPI stays neutral with regard to jurisdictional claims in published maps and institutional affiliations.

(C) 2020 by the authors. Licensee MDPI, Basel, Switzerland. This article is an open access article distributed under the terms and conditions of the Creative Commons Attribution (CC BY) license (http://creativecommons.org/licenses/by/4.0/). 